\title{
Implementation of Character Values of Environmental Care in Geography Learning at SMA Negeri 1 Kinali
}

\author{
Arnapis Jambak \\ Students of Master Program (S2) of Geography Education Program, \\ Faculty of Social Sciences, Universitas Negeri Padang \\ Email: arnapis.jambak90@gmail.com
}

\begin{abstract}
This research aims to discuss and analyze how teachers and school leadership roles in implementing character values of environmental care in teaching geography to learners in SMA Negeri 1 Kinali. This study used a qualitative approach that aimed to describe the systematic, factual, and accurate information on the phenomenon in detail. Selection of the subject of research was conducted by the method of purposive sampling, where the School leaders, teachers, and learners with data collection through observation, interviews, and documentation based on the validity of the data with triangulation techniques and perseverance observation. In analyzing the data, the researcher used stages: data reduction, data presentation, and inference. The results of the study are as follows: 1) The school environment plays an important role in shaping the behavior of learners, 2) How teachers implement the character values in shaping the attitude of the environment care which was done by: (a) Integrating into the planning and implementation of learning geography through the preparation of syllabus, RPP and material by incorporating the values of characters in accordance with the demands of $\mathrm{SK}$ and $\mathrm{KD}$, (b) organizing a routine activity held by the school, 3 ) the role of school leaders in the formation of the character values of learners with: (a) Development of school curriculum through the regulatory policies of the school and extra-curricular activities so as to establish the values of the expected character. (b) Development exemplary school leaders and teachers in motivating learners and cultural activities of the school, 4) How learners implement the values of character care about the environment through self-development program in schools and school activities related to the character values of environmental care, 5) Barriers to implement the characters values in SMA 1 Kinali due to school rules are not optimally running, so that the students' participation is still low in preserving the environment, lack of awareness of students to care about the environment both at school and at home, and yet optimal work together with the parents of students in the formation of character values for caring environment on the learner.
\end{abstract}

Keywords: Character Value, Implementation, Environmental Care.

\section{Introduction}

Education is one of the determining factors for the progress of a nation. The quality of education affects the quality of human resources in order to build and enhance the overall development of the nation. Education has a very important role in generating qualified human resources so that the results of the educational process to meet the guidance of science and technology for the future. Through the Ministry of Education since 2010, has launched the implementation of character education for all levels of formal education. Implementation of character education on the level of formal education took place in educational institutions kindergarten, elementary, junior high, high school, vocational school, to university. To apply a character value in each lesson, the teacher has a duty to encourage, guide, and provide learning facilities for students to achieve the goal. Thus, students can be motivated to create effective and efficient learning conditions as a starting point to improve themselves in achieving optimal learning results (Slameto, 2010).

According to Thomas Lickona (in Wibowo, 2012: 32), the character of a person's natural properties is built, so that the future generation has an attitude and mindset that is based on solid moral and right. This trait is manifested in concrete actions through good behaviour, honest, responsible, and respectful of others and 
other noble characters. According to Bintoro (in Sulistyowati 2012), the character education aims to improve the implementation and results of education at the school as a whole, integrated and balanced, in accordance with competency standards. Character education is not enough recognition of cognitive value but must be coupled with effective appreciation in value, and finally experience real value outside of school.

Character education has become a major issue of education. Besides being part of the process of establishing the morals of the nation, character education is expected to be the main foundation in increasing the degree and dignity of the Indonesian nation. The character formation begins from a God-given nature which then forms the identity of behaviour. In this natural disposition process, it is strongly influenced by environmental conditions so that the environment has a significant role in shaping your own self and behaviour. Schools and communities as part of the environment have a very important role. Therefore, every school and community should have the discipline and the habits of the character that will be formed (Prayitno, 2011). The school environment can be a good education for learners of character growth. All the events that occur in school can be integrated into the character education program so that what is learned at school will affect his character. Implementation of character education in schools is developed through learning experiences that lead to the formation of character in the self-learners. Character education in teaching and learning activities in the classroom, implemented is using an integrated approach in all subjects. Thus, the education that is needed today is to integrate education with teaching character education so as to optimize the entire dimension of child development, namely; cognitive, physical, social, emotional, and spiritual creativity (Sulistyowati 2012).

However, building a character is not a job that instant and simultaneous, but a job that requires a long process and synergy. The education process is a system that consists of input, process and output. Input is the learners who will carry out the learning activities, the process of teaching and learning activities, while the output is the result of a process undertaken. From the implementation of the educational process is expected to produce qualified human resources and high competitiveness to face the global competition today. In the learning process teachers are required to understand the characteristics of students well, this is because of input factors indicate that the diversity of the student's attitude, style of learning, knowledge and distinction ability is a component that gives the impact which is very important to what is actually learners learned (Killen, 1998: 5). Meanwhile, to support the creation of a learning process that can encourage the development of student potential in a comprehensive manner, the teacher must have the insight and the frame of a holistic, because learning must be able to encourage the growth of liveliness and creativity optimum of students who can develop the potential of students overall and integrated, and the end result is a change in the behavior of learners in achieving the intended learning objectives (Aunurrahman, 2009).

One of the characters is no less important for the self-learners instilled from an early age are a caring attitude towards the environment. The value of environmental care code in the form of attitude and action seeks to prevent damage to the surrounding natural environment. In addition, with the value of environmental care in the world character education can be aimed at developing measures to repair environmental damage that has occurred in growing concern and awareness of the importance of protecting the environment students can create a healthy school environment and convenient. In order for a healthy and comfortable environment can be realized, each individual has a role to train and retain good behaviour to the surrounding environment in order to improve the performance and creativity of learners.

The development of environmental education at the upper secondary level students can be done through the integration of environmental issues in learning geography. Because of geography teaching materials, related character values environmental care need to be developed and linked to the context of everyday life. Thus, learning the values of character care about the environment not only on the cognitive level but touched on the real experiences in the lives of young people in the community daily (Salirawati: 2012). Geography as one of the subjects taught in high school can play a role in instilling positive values that will be the character of self-learners. Various environmental problems that exist around the learner are an interesting topic that can be used as a means to cultivate an attitude of care for the environment on the learner through learning geography. Examples of the environmental problems associated with learning materials geography are; pollution, environmental destruction and the risk of both natural and human actions. Highlights in environmental conservation and sustainable development are one of geography in high school learning materials are closely related to the phenomenon.

With the knowledge gained, the student should be in character and act smart, wise and environmentally responsible. But in fact, in achieving the learning objectives are still the problems were 
found leading to the level of awareness of students to the environment is still low, as still littering that do not fit in place, the lack of awareness of students in maintaining the park class, their nature is indifferent among students in violation of cleanliness. Meanwhile, another problem is the actions of students like cheating when they have exam as if it has become a culture, smoking on school premises, the students who did not follow the ceremony, the dishonesty while shopping in the school cafeteria, and parking motorcycle is not in place, so that chaotic impressed with the layout, as well as etiquette or manners some students are still lacking. This is evident from the way students respond when a strike by teachers, they sometimes argue with words that tend to be rough.

In line with the above explanation, the researchers conducted observations while that of the kinds of problems mentioned above are still encountered from some students at SMA Negeri 1 Kinali who do not have the character of care for the environment, for example, there are students who are seen littering such as in a desk drawer, in flowerpots, sweeping waste paper into the gutter, students who throw food waste to the back of the classroom through the window, students who do not care about the environment dirty and damaged by the graffiti either on the wall or on grade, wasteful use of water and indifference in the neatness of dress uniforms. Of the various problems experienced by schools, mental revolution needed to build national character, because given SMA Negeri 1 Kinali adjacent to the processing mills palm oil can be used as a means of appealing to cultivate an attitude of care for the environment on the learner. Character education environmental care is required to overcome the crisis of character because it can provide an effective instructional practice to develop environmentally responsible behaviour which is considered as an alternative to preventive properties because of the education building a new generation of the nation for the better.

\section{Methods}

Based on the problems and goals to be achieved in this research is to analyze and discuss the role of school leaders in coaching the character values and how teachers implement environmentally conscious character values in SMA Negeri 1 Kinali. This study used qualitative research methods. Qualitative research is research that produced the data description of the form of words written or spoken of people and behaviours of interest that aims to describe systematic, factual, and accurate information on the facts and the nature of specific populations or try to describe the phenomenon in detail. Data was obtained from the research informants by using a purposive sampling of School leaders, teachers, and students of SMA Kinali. Data collected through observation, interviews, documentation and followed by checking the validity of the data based on the degree of confidence through triangulation technique, perseverance observation. In analyzing the data used stages: data reduction, data presentation, and inference.

\section{Results and Discussion}

\section{Utilization of Environmental Conditions SMA N 1 Kinali}

School as formal education institutions have a responsibility to find, cultivate and hone the ability to think, the ability to process and skills of learners in determining the decision to act, because in the school environment can develop values that create as well as the behavioral patterns of individual potential of learners so that they can grow through the process of learning both in the classroom and outside the classroom. The school environment can be a good education for the growth of the student's character, because of all the events that occur in the school should be able to be ground for students in developing capabilities in an effort to integrate values through character education programs that are applied either directly or indirectly in direct (Koesoema, 2010). Based on the above explanation regarding the implementation of character education in the use of environmental conditions in SMA Negeri 1 Kinali, it can be concluded that:

a) Character education in schools can be done when the whole school community supports all activities envisioned in the empowerment of all the resources of the school's effort in embedding character value by pledging good things, such as in environmental care programs, namely: Meet Diamonds, Decorate class garden and plant life pharmacies. So that learners are able to act to care for, maintain and preserve the environment based on the values to be his personality. 
b) The neighbourhood around the school should take support in order to improve the quality of education by creating an atmosphere conducive to proper learning place for students in the school environment. Because the school environment is a supporting factor in the growth of values to students, by making the school environment as a container planting sense of concern for the environment in the learning process.

c) Teachers must be able to produce learning related to the values and norms associated with the context of everyday life. Because through learning, learners can understand the good behaviour to appreciate relationships with others and is able to provide a real experience to students with the skills to not damage the environment.

d) The teacher always gives motivation for learners to always care about the environment. Because learners become the object of cultural development, which is certainly expected to be a boost in applying the values of characters one of them is environmental care.

\section{How Teachers Implement Character values of Environmental Care in Learning Geography.}

\section{a) Integrating Character Values in Geography Subject}

Jamal Ma'mur Asmani (2011) also states that the integrated character education in learning is the introduction of values, gained awareness of the importance of values, and internalization of values into the behavior of participants' daily learner through a learning process, which takes place both inside and outside the classroom in all subjects. Learning objectives to be achieved is that learners can master the material being taught and to make learners know, realize or care, and internalize the values in the form of behaviour.

Based on the research results, the integration of character education in the subjects of geography implemented by geography teacher at SMA Negeri 1 Kinali to perform based learning environment, namely:

1) Integrating the teachers of geography in the planning stages of learning include the syllabus that includes character values corresponding to demands SK and KD, synchronizing the syllabus into the RPP which is reflected in the opening phase, core activities, and activities cover as well as teaching materials adapted from the verses of the Al-Quran, so that learning geography learners can pursue the planting of character values environmentally appropriate with the material both in school and at home respectively.

2) The integration of character values environmental care in teaching geography is reflected in the active learning that teachers do in the classroom, such as teacher child's attention by linking the material with real events; the teacher gives motivation to the learners in understanding the purpose of the material and teachers guide children to apply the value character in daily life. Because in the process of learning, learners are subject to the achievement of learning to instil character values one character value of environmental care.

3) The integration of character values in the learning environment care can be seen with the participation of teachers who facilitate learners as a motivator and participants to provide feedback, in order to measure the academic achievement and personal development of students through awards to students who play a role in implementing value- values in everyday life in schools and teachers were also involved directly with the environment that continues to provide an example in instilling the values of character care about the environment so as to achieve the expected learning goals.

\section{b) Self Development Program Through School Routine Event}

Based on the research, routine activities conducted in SMA Negeri 1 Kinali relating to the implementation of character education in an effort to instil character values of environment care on learners, namely:

1) Through regular activity classes of the students are required to come at 07:15 because before entering the classroom the students are required to clean classroom and after the bell rang, the students lined up before the class and the teacher greeted one by one, followed by praying, selawat nabi, reading asmaulhusna together for approximately for 10-15 minutes. Furthermore, in the hours after school characterized by the bell rang and followed by songs compulsory.

2) Through regular activities of the school, the environment clean activities are cleaning the schoolyard before the semester exams or when commemorating National holidays. 
3) Through weekly activities, namely "Jumpa Berlian" (Friday Morning of Clean Environment). This activity conference activities include mutual cooperation for schools environmental cleanup that implemented by the entire school community. In addition, a kind of Kultum Muadharah activities conducted every Friday morning in lieu of environmentally clean activities, because of mutual cooperation is held once in two weeks of each month with the goal of getting tausiah learners to deepen the faith as a provision in the future.

3. School leadership role in fostering Character Values of Environmental Care in SMA N 1 Kinali.

a. School Curriculum Development

1. Through Self Development Program of School Regulations

Mulyasa(2011) suggests that one of the strategies of implementation of character education is through the role of the principal in the implementation of the regulation school program for realizing the habits and characteristics of learners in developing their potential mainly concern on the environment. In the implementation of activities that can be habituation is routine clean the environment by learners in school continuously and consistently in implementing them, one of them if the students violate school rules then sanction or reward founded in the form of punishment that associates with cleaning the school environment as learning can provide a special meaning for students.

Based on this research, routine activities undertook resident of SMA Negeri 1 Kinali in efforts to implement school rules on environmental management, namely:

a) Through the activities before the learning begins, the students perform a clean environment by cleaning scheduled class every day before and after school. Such as taking out the trash by trash, sweep the classroom and the yard, watering the flowers, as well as take water. With the routine of habituation is expected to form the learners who can do things that reflect the care for the environment without knowing it, because already accustomed to and is internalized in self-learners to behave in a caring environment.

b) Through the planned curriculum development school in integrating environmental care character value to learners is by organizing competitions cleanliness class at least once a year, so that students feel the appreciation from the school authorities of the results of what they have done for the school so far. In addition, the school also held a means for students to develop their potential by way of farming through hydroponic crops and plants pharmacy in the garden grown.

c) Through regular activities outside the classroom, namely: for students who come late to school, the class teacher asks the students to report to on-duty teachers. Usually, before entering the classroom, the students were given punishment/sanctions such as cleaning the yard office and throw garbage into the landfill and after that learners gain weight five points as a reward for the school diary. In addition, teachers and learners are required to pray in congregation in the mosque by optimizing the existing infrastructure in the school to achieve the expected educational goals of the school.

2. Personal Development Program through extracurricular activities

Gunawan (2012) the activities of student coaching or often referred to as extra-curricular activities are educational activities conducted outside school hours face to face. This activity is conducted to form a complete human being who can help the development of learners in accordance with the needs, potential, talents, and interests through activities that are specifically organized by teachers or educators capable and in authority at school.

Character education in SMA 1 Kinali also implemented through extra-curricular activities of the school with providing space and facilities to embody the personality of learners who seek to establish a social life, concern for the environment and preparing a career for students for the challenges in the future such as:

a) Through the Students' Union (OSIS) for learners is a training vessel for coordination in creating in collaboration between groups of students will organize activities within the school and outside of school. Such as holding an "EKSPRESI" event in SMA Negeri 1 Kinali is up to seven, it indicates that the role of the council greatly helps the implementation of this annual event. Due to that good communication between each other awake school and become a partner for other organizations that exist in schools to help provide a smooth and comfort. 
b) Through the school scouting activities can be character building for learners in piety towards God Almighty, national and state life and form the character of the personality of students so that it can be a character in accordance with the noble values. In addition, there are also activities extra-curricular that can shape the character of the students are Sispala, KKR, PMR, Paskus, Annisa, Assalam, Field of art as well as the field of sports which can be a talent development program so that a potentially useful for learners to challenge in the future will come.

b. Development in the Learning Process

1. Modeling in Embedding Character for Learners.

Implementation of character education for environmental awareness is supported by exemplary principals and teachers. Principals and teachers as educators continue to give an example and become role models for students. This is in accordance with the Ministry of National Education (2010), who said that the example is the behaviour and attitude of principals, teachers and other education personnel in giving a good example to the students. Exemplary principals cannot be separated from the role of the principal itself.

Based on this research, exemplary given principals and teachers to students to implement the values of characters in giving the example shown in everyday life by way:

a) Through daily activities outside the classroom are: principals and teachers wear uniforms neat and clean in accordance with applicable rules, spoken greetings were good with the school community 5S (Smile, Greeting, Call, Polite, Courteous) as well as not smoking in front of students in the school environment. Moreover, the principal responsible for empowering the school community to be able to participate in giving the example of the school environment as standing immediately clean up the environment either Friday or on another great day, watering the plants in the yard office, always encourage and motivate learners to throw trash in the trash. Teachers provide exemplary to students by way of cleaning the yard took classes together, planting a variety of flowers both in the classroom and a garden courtyard toga, and appreciate learners for caring for houseplants class.

b) Through the daily activities in the classroom are: Teachers in the learning process always gives motivation for learners to improve sensitivity to environmental conditions. Motivation gave them by giving penalties for students who break the rules and give a reprimand and penalties for students caught for not keeping the school environment as well as the appreciation of praise and prizes in competitions held school-based environments such as race hygiene class and race park class.

2. Role of School Culture in the Embedding Character for Learners

Formation environmentally conscious school culture will shape students to be more environmentally sensitive. Ministry of Education (2010) states that the school culture is the atmosphere of the school in which the students interact with peers, principals, teachers, and other school community. Social interactions are bound by the rules, norms, morals and ethics in schools.

Based on the research results, developed a school culture with regard to the implementation of environmental awareness of character education in SMA 1 Kinali are:

a) Through "Jumpa Berlian" that Friday morning the Clean Environment. Programs that are cultivated ornamental garden including class race, the race between extracurricular and maintain and care for the garden plant life pharmacies in Toga. Put up posters that are useful in the school environment, such as a poster with the theme of cleanliness and educational posters.

b) Through the daily activities of learners are given the responsibility to use the school attributes complete accordance with the provisions of the school, maintaining and caring for the availability of hygiene in the classroom, the students were briefed to always separate organic and non-organic, neatness in a parked vehicle, providing motivation to conduct social activities, show civility and mutual respect among colleagues, invite pray together throughout the school community, the processing of waste into economically valuable materials through entrepreneurial activity, and greening the school environment.

c) Through school programs, pattern provided by principals and teachers to develop programs activities that can implement character values to learners regarding the allocation of the effective time in the academic calendar, for example: learners participate to celebrate the environment, 
involving learners in the event commemorate the teachers and prepare students with the skills through school entrepreneurship program, held once a year, and give rewards or awards to the students who earned the cleanest students based on assessment of teachers is given once a semester. By doing so, learners can foster feelings of love for environment and empathy for others who are expected to make real act learners in daily habits.

4. How Students Implement Character Values of Environmental Care In Everyday Life.

a. Implementing Character Values of Environmental Care in Personal Development Program in Schools.

In the process of embedding on the character of the learners in the school environment can be implemented by making exemplary and habituation as the primary method to bring learners to the introduction of cognitive value, appreciation of the value effectively, and finally experience real value. SMAN 1 Kinali learners can develop the character value by creating a climate and culture and environment conducive as an effective medium in character education care for the environment, namely by:

1) Through a program launched by the school is to hold a briefing and counseling through the school and from outside the school such as the Department of Health and the Department of Forestry to provide insights into the viewpoint of the environmental benefits to be maintained to explain the extensive damage to nature, foster reasoning learners to find out why people should care about the environment, as well as build awareness of learners to understand themselves to improve attitudes are less concerned about the environment.

2) The school held a contest related to hygiene routine and periodic of each semester, in order to pump the motivation of learners in preserving the school environment which is supported by the availability of facilities and infrastructure that can support the development of a learning process that is not fixated on learning in the room or classroom, but can optimize the school environment as a laboratory practicum for students to cultivate the value of caring for the environment.

\section{b. Implementing Character Values of Environment Care Outside the School}

Development of the learning process outside of school which is implemented by SMA N 1 Kinali in the implementation of character education is to increase environmental awareness hour or extracurricular activities and involve learners in activities in the school environment. This is in accordance with the Ministry of National Education (2010: 22) which states that the development of the learning process outside of school through extra-curricular activities and other activities that are followed by all or part of the students, designed the school since the beginning of the school year, and put in Calendar Academic.

Activities outside of school include extra-curricular activities are conducted outside of school learning include:

1) Activities of scouting with the work of cleaning the terminal area of waste dumped traders, participated in raising funds from public donations when there is a disaster, and participate in the activities of agencies related to the environment and forests.

2) Activities of the Youth Red Cross (PMR) such as blood donation level districts in collaboration with the Department of Health (Puskesmas Subdistrict Kinali),

3) Student Organization (OSIS) by raising funds for the mosque, activities healthy walk around the school on the days of such PGRI anniversary,

4) KKR team in cooperation with PMR chosen as representing the school Activity Unit West Pasaman in the event the health and cleanliness of the school environment.

5) School Security Force Activity (MCC) who took part in regulating vehicular traffic in the morning hours before entering the classroom.

\section{Educational Barriers to Implementing Character Values of Environmental Care in SMA Negeri 1} Kinali.

a. Constraints on School Rules

In order to implement school management character, the school is expected to do the planning, conducting, and evaluation of each educational component in which includes character values are 
integrated, which means fostering the values of characters in accordance with the characteristic of the school itself. However, all is not running smoothly as expected. There were still found obstacles encountered in implementing the character values among students, especially in caring for the environment.

Based on the research results, it can researchers conclude about problems in the school in the implementation of the rules-based environment in SMA Negeri 1 Kinali, are as follows:

1) The vision, mission and goals of SMA $N 1$ Kinali relating to management efforts and environmental protection have not looked in writing, therefore the school program as a diamond conference (Friday morning, clean environment), mutual assistance and cooperation for cultivation is still difficult to be used in the school environment.

2) Regulatory environment based not running optimally since the policy regarding penalties associated with keeping the environment there are still some who did not understand the importance of the active participation cultivate learners in habituation to act and behave in accordance with the expected character.

\section{b. Constraints in Learning Process}

In implementing the character values in learners need active learning by involving learners in learning, point to the formation of the competence of learners who are targeted to solve various problems. Therefore, students should be encouraged to interpret the information given by the teacher in order to achieve the same sense of any material (Mulyasa, 130-134: 2011). However, based on research results, which the obstacles to implementing the character values in the process-based learning environment in SMA Negeri 1 Kinali are as follows:

1) Preparation of teachers in the implementation of learning that associates with the concern of students to the environmental conditions in the classroom are still not active because teachers still riveted and preoccupied with chasing the target in completing the subject matter which is considered the purpose of learning.

2) Preparation of teachers in presenting learning material that is not maximized, because teachers are difficult to provide the closest example to their lives so that teachers are constrained in motivating learners in fostering their awareness of environmental benefits for life.

\section{c. Constraints outside of school}

in order to succeed the character education in the schools, need to be empowered environment both physical environment and social environment and community resources optimally, the school through the role of school principals and teachers in the development of the character values learners should collaborate with the elements Related deemed to support efforts to develop the quality and the quality of education is to establish a relationship with the community around the school. However, in implementing the value of the character on the learner persistence of the problems were found on the influence of the environment around the school.

Based on the research results, it can be concluded that the obstacle in the formation of character values environmental care in SMA 1 Kinali are as follows:

1) Awareness of students to care for the environment is still lacking. For example, there are still many students who litter. The reasons for that is the habit of littering in the house but left by his parents, and students are more afraid because supervised by teachers than aware of his actions were wrong.

2) Lack of awareness of students to participate in extracurricular activities in an effort to train and familiarize learners with positive activism has not materialized fully because they assume extracurricular event just kidding.

3) Not maximal communication with family school learners in fostering values such as custom character ignoring learners scattered rubbish taken to the school environment.

4) Not to routine meetings between the homeroom / the school and the parents of learners in attitude or personality development of students, the other reason the parents of learners assume every child coming to school means they are in trouble. 


\section{Conclusion}

Based on the results of research and discussion, it can be concluded that the implementation of character values of environmental care in SMA Negeri 1 Kinali by utilizing the school environment can play an important role in shaping the behavior of students with their school program which requires students to skilled, creative and innovative in the learning process, the way teachers implement character education by integrating the values of character of environment care for learning geography contained in the planning stages of learning and implementation of active learning, as well as direct participation in the planting of character values and through a program of regular activities classroom, school and weekly program. The role of school leaders are through (a) the development of school curriculum through rules that proclaimed school and through extra-curricular activities (b) development in the process of learning by modelling and through the culture of the school. How learners implement character values in the learning process in the school and outside of school. Whereas the barriers to implementing it due to school rules are not optimal regarding the participation of learners in the environment, the lack of awareness of students both at school and at home in developing the character value of environmental care, and not maximal cooperation with the parents of students in fostering characters values of environment care on the learner.

\section{Reference}

Afandi, Rifki. (2011). "Integrasi Pendidikan Karakter Dalam Pembelajaran IPS di Sekolah Dasar". Fakultas Keguruan dan Ilmu Pendidikan. Universitas Muhammadiyah Sidoarjo.

Agusli. (2012). "Pendidikan Karakter dalam Pembentukan Sikap profesional Polri di Sekolah Kepolisian Negara (SPN) Padang Besi". Disertasi. UNP. Padang:

Aunurrahman. (2009). "Belajar dan Pembelajaran". Bandung. Alfabeta

Dianti, Puspa. (2014). "Integrasi Pendidikan Karakter Dalam Pembelajaran Pendidikan Kewarganegaraan untuk Mengembangkan Karakter Siswa". Prodi Pendidikan Kewarganegaraan, SPs, UPI.

Ernawati. (2015). "Perilaku Peduli Lingkungan pada Sekolah Alam Studi Kasus di Kota Padang". Disertasi. UNP. Padang

Gunawan, Heri. (2012). "Pendidikan Karakter Konsep dan Implementasi". Bandung. CV Alfabeta

Hidayat, Nur dan Sundari. (2014). "Integrasi Nilai Karakter Peduli Lingkungan Hidup dalam Pembelajaran Akidah Akhlak di MI". Fakultas Ilmu Tarbiyah dan Keguruan, UIN Suka Yogyakarta

Huda, Imam Arif Fai'ilah Syaiful. (2010). "Implementasi Pelaksanaan Pendidikan Karakter terintegrasi dalam Proses Pembelajaran Mata Pelajaran Geografi di SMA". (http://imamvaillah.blogspot.com/2013/02/resume-implementasi pelaksanaan.html.

Jamal Ma'mur Asmani.(2012). "Buku Panduan Internalisasi Pendidikan Karakter di Sekolah". Yogyakarta: Diva Press.

Julaiha, Siti. (2014). "Implementasi Pendidikan Karakter Dalam Pembelajaran". STAIN Samarinda.

Kaimuddin. (2014). "Implementasi Pendidikan Karakter Dalam Kurikulum 2013". Dosen UIN Alauddin Makassar.

Kemendikbud. (2010). "Dokumen Kurikulum 2017". Diakses dari (http://muna.staff.stainsalatiga.ac.id/ dokumen-kurikulum-2017.pdf)

Koesoema, Doni. (2010). "Pendidikan Karakter Strategi Mendidik Anak di Zaman Global". Jakarta: Grasindo 
Lufri dan Ardi. (2000). "Metodologi Penelitian". Padang. UNP

Marfuatin, Uliya. (2016). "Implementasi Pendidikan Karakter Kurikulum 2013 pada Mata Pelajaran Prakarya dan Kewirausahaan di SMK Negeri 9 Surakarta Tahun Pelajaran 2015/2016". Fakultas Keguruan dan Ilmu Pendidikan, Universitas Muhamadiyah Surakarta. Surakarta.

Mukminin, Amirul. (2014). "Strategi Pembentukan Karakter Peduli Lingkungan di Sekolah Adiwiyata Mandiri". IAIN, Sulthan Thahah Saifuddin.

Mulyasa, E. (2011). "Manajemen Pendidikan Karakter". Jakarta: Bumi Aksara

Narwanti, Sri. (2011). "Pendidikan Karakter". Yogyakarta: Familia

Nasrullah. (2015). "Upaya Guru Pendidikan Agama Islam dalam Membentuk Karakter Siswa". Sekolah Tinggi Ilmu Syariah Al-Ittihad. Bima

Prayitno and Belferik Manulang. (2011). "Pendidikan Karakter dalam Pembangunan Bangsa". Jakarta: Grasindo.

Rohani, Kusnadi. (2014). "Pembelajaran Berbasis Nilai Karakter dalam Upaya Pengembangan Kearifan Lokal Budaya Melayu Riau". Dosen Fakultas Tarbiyah dan Keguruan, UIN SUSKA Riau.

Salirawati, D. (2012). "Percaya Diri, Keingintahuan, dan Berjiwa Wirausaha: Tiga Karakter Penting Bagi Peserta Didik". FMIPA Universitas Negeri Yogyakarta. Jurnal Pendidikan Karakter 2 (2):213-224.

Slameto. (2010). "Belajar dan Faktor Faktor yang Mempengaruhinya". Jakarta: PT. RINEKA CIPTA

Subardiyono. (2015). "Peningkatan Sikap Peduli Lingkungan, Keterampilan Berpikir Kritis, dan Hasil Belajar IPS Melalui Scientific Method". Universitas PGRI Yogyakarta.

Sugandi, Dede. (2015). "Pembelajaran Geografi Sebagai Salah Satu Dasar Pembentukan Karakter Bangsa. Dosen Senior di Departemen Pendidikan Geografi FPIPS UPI (Fakultas Pendidikan Ilmu Pengetahuan Sosial, Universitas Pendidikan Indonesia)". Bandung.

Sulistyowati, Endah. (2012). "Implementasi Kurikulum Pendidikan Karakter". Yogyakarta: PT. Citra Aji Parama.

Tisa, Purwani Linda. (2014). "Implikasi Nilai Karakter Peduli Lingkungan di Madrasah Ibtidaiyah Negeri (MIN) Kebonagung Imogiri Bantul". Program Studi Pendidikan Guru Madrasah Ibtidaiyah, Fakultas Ilmu Tarbiyah Dan Keguruan, Universitas Negeri Sunan Kalijaga.

Trihantoyo, Syunu. (2013). "Peranan Kepemimpinan Kepala Sekolah dalam Menumbuhkan Nilai Karakter". Jurusan Manajemen Pendidikan, Fakultas Ilmu Pendidikan, Universitas Negeri Surabaya.

Wahyuni, Uri. (2013). "Peran Guru Dalam Membentuk Karakter Siswa di SD Negeri Jigu dan Triharjo Pandak Bantul Tahun Pelajaran 2014/2015". Pendidikan Guru Sekolah Dasar, Fakultas Keguruan dan Ilmu Pendidikan, Universitas PGRI Yogyakarta.

Wibowo, Agus. (2012). "Pendidikan Karakter". Yogyakarta: Pustaka Pelajar 